\title{
Studies on Pectase
}

\author{
By MARGARET HOLDEN, Rothamsted Experimental Station, Harpenden, Herts
}

(Received 18 October 1945)

A previous paper (Holden, 1945) described a $\mathrm{pH}$ drift towards the acid side in minced tobacco leaves when the $\mathrm{pH}$ was raised to $\mathrm{pH} 8$ by addition of $\mathrm{NaOH}$, due mainly to the enzymic demethylation of pectin by pectase. The present paper concerns the extraction, some properties and the partial purification of tobacco leaf pectase and gives some account of the pectase distribution in the leaves of other species. Recent papers by Lineweaver \& Ballou (1945) and MacDonnell, Jansen \& Lineweaver (1945) have dealt with the effect of cations on the activity of alfalfa pectase and with the properties of orange pectase. The results reported here on the extraction of tobacco pectase are similar to those obtained by the other workers for orange pectase, but the properties of the enzyme from various sources appear to differ to some extent.

\section{MATERIAL AND METHODS}

Leaves of Nicotiana tabacum var. White Burley from glasshouse plants were used for most of the work and leaves of wild woody nightshade (Solanum dulcamara) when tobacco was not available. Other plants used are listed below. The leaves were minced twice in a domestic mincer and the sap squeezed out by hand through madapollam. The residue, referred to as fibre, was washed twice with a volume of distilled water approximately the same as that of the sap, and squeezed dry. Fibre that had been ground in a tripleroller mill as described by Bawden \& Pirie (1944) is called milled fibre. The recorded weights of both these fibres are the wet weights after squeezing by hand, the material then containing about $75 \%$ of water. Measurements of $\mathrm{pH}$ were made with a glass electrode.

Measurement of activity. The breakdown of pectin to pectic acid and methanol by pectase was followed by determining the amount of methanol liberated. The substrate used was a solution of citrus pectin (British Drug Houses Ltd., 100 grade) with a moisture content of $10 \%$ and an ash content of $1.4 \%$. The methoxyl content, on a moisture and ash-free basis, as determined by Zeisel's method was $5.4 \%$. The pectin solution had a $\mathrm{pH}$ of $3 \cdot 1$ and was not neutralized until just before activity tests were carried out. The tests were made in phosphate buffer solution which minimized any $\mathrm{pH}$ drift. A sample, $0 \cdot 1-1 \cdot 0 \mathrm{ml}$. of the solution to be tested was added to the buffer-substrate which consisted of $5 \mathrm{ml}$. pectin solution $(8 \mathrm{mg} . / \mathrm{ml})+.5 \mathrm{ml}$. $0 \cdot 2 \mathrm{M}-\mathrm{Na}_{2} \mathrm{HPO}_{4}$ previously adjusted to $\mathrm{pH} 8.0$ with $\mathrm{HCl}$. After $10 \mathrm{~min}$., $1 \mathrm{ml} .2 \mathrm{~N}-\mathrm{HCl}$ was added to lower the $\mathrm{pH}$ and stop the reaction. Methanol was determined on a $5 \mathrm{ml}$. sample by the method previously described (Holden, 1945). It was necessary first to distil the sample in the Markham steam distillation apparatus (Markham, 1942), for unless this was done the red colour developed differed from that of the standards; moreover, many of the samples to be tested were coloured. If there was any gel formation on the addition of acid the test was repeated using a smaller amount of enzyme solution as this indicated such extensive demethylation that the assay of the enzyme was no longer precise. The amount of methanol due to non-enzymic demethylation at $\mathrm{pH} 8$ in $10 \mathrm{~min}$. was barely detectable.

One unit of enzyme is defined as the amount which will liberate $32 \mathrm{mg}$. methanol from pectin in $1 \mathrm{~min}$. in $0.1 \mathrm{M}$ phosphate solution at pH 8 and $20^{\circ}$. Except for the temperature, the unit is the same as that used by Lineweaver et al. The purity of preparations is expressed as units per mg. dry weight of material precipitable with trichloroacetic acid.

\section{Preliminary observations on the preparation of the enzyme}

Extraction. It had been found previously that pectase could be obtained from the washed milled fibre of tobacco leaves by extraction at $\mathrm{pH} 8$ either with $\mathrm{NaOH}$ or with phosphate solution, but that water extracts at $\mathrm{pH} 6$, the natural $\mathrm{pH}$ of the fibre suspension, had little or no activity. A quantitative comparison was made of the activity of water, $5 \%$ $\mathrm{NaCl}$ extracts at $\mathrm{pH} 6$, and of phosphate extracts at pH 6 and 8 using $10 \mathrm{~g}$. portions of milled fibre. Table 1 shows that increase in the concentration of salt brings about extraction at $\mathrm{pH}$, but that extraction at pH 8 is more effective.

\section{Table 1. Influence of salt and $\mathrm{pH}$ on extraction of pectase from tobacco fibre}

(Portions of milled fibre (10 g.) extracted with $80 \mathrm{ml}$. solution at $20^{\circ}$ for $2 \mathrm{hr}$.)

$\begin{array}{ccc}\mathrm{pH} & \text { Extracting solution } & \text { Activity units } \\ 6 & \text { Water } & 0 \cdot 015 \\ 6 & 5 \% \mathrm{NaCl} & 0 \cdot 60 \\ 6 & 0 \cdot 2 \mathrm{M}-\mathrm{Na}_{2} \mathrm{HPO}_{4} & 0 \cdot 55 \\ 8 & 0 \cdot 2 \mathrm{M}-\mathrm{Na}_{2} \mathrm{HPO}_{4} & 0 \cdot 78\end{array}$

A comparison was made of the activity of successive extracts at $\mathrm{pH} 8$ from $9 \cdot 3 \mathrm{~g}$. portions of milled fibre made both with $\mathrm{NaOH}$ and with $0.2 \mathrm{M}$ $\mathrm{Na}_{2} \mathrm{HPO}_{4}$ extractants and from $15 \mathrm{~g}$. minced fibre in phosphate solution (9.3 g. milled fibre obtained from $15 \mathrm{~g}$. minced fibre). The fibre was soaked in the extracting solution for $2 \mathrm{hr}$; the $\mathrm{NaOH}$ extracted portion was maintained at $\mathrm{pH} 8$ by addition 
of alkali at intervals. The results in Table 2 show that extraction with phosphate is more efficient than that with $\mathrm{NaOH}$, due to the increased salt concentration. With milled fibre the first extract

\section{Table 2. Extraction of pectase from milled and minced fibre at $\mathrm{pH} 8$}

(Portions of milled fibre $(9 \cdot 3$ g.) and the equivalent amount in minced fibre $(15 \mathrm{~g}$.) extracted with $80 \mathrm{ml}$. solution for $2 \mathrm{hr}$.)

\begin{tabular}{|c|c|c|c|}
\hline \multirow[b]{3}{*}{ Extract } & \multicolumn{3}{|c|}{ Activity units } \\
\hline & \multicolumn{2}{|c|}{ Milled fibre } & \multirow{2}{*}{$\begin{array}{l}\text { Minced } \\
\text { fibre } \\
\text { Phosphat }\end{array}$} \\
\hline & $\mathrm{NaOH}$ & Phosphate & \\
\hline $\begin{array}{l}1 \\
2 \\
3\end{array}$ & $\begin{array}{l}0.14 \\
0.07 \\
0.03\end{array}$ & $\begin{array}{l}0.58 \\
0 \cdot 12 \\
0.07\end{array}$ & $\begin{array}{l}0 \cdot 29 \\
0 \cdot 17 \\
0 \cdot 07\end{array}$ \\
\hline & 0.24 & 0.77 & 0.53 \\
\hline
\end{tabular}

has by far the highest activity, whereas with minced fibre the extraction is slower. About $70 \%$ of the amount of enzyme that can be obtained from milled fibre is extractable from minced fibre. It was therefore found unnecessary to mill the fibre, which was an advantage since less time was needed for making a preparation. Minced-fibre extracts contain much less total protein than milled-fibre extracts so that the former enzyme preparations had a higher initial specific activity.

Sap-soluble enzyme. The distribution of pectase between the sap and fibre was next investigated. It was found that in most batches of leaves only a small proportion (from 5 to $10 \%$ of the total amount of enzyme) was present in the sap, but in two batches of leaves, to be considered later, over $25 \%$ was sapsoluble. The comparatively low activity of the sap, combined with its high soluble protein content make it unsuitable as a source of enzyme. Sap that had been centrifuged to remove cell debris and chloroplast material had an activity of 0.00016 unit $/ \mathrm{mg}$. dry weight, whereas a phosphate extract of fibre, before purification, had an activity more than twenty times this value.

Ethanol and ammonium sulphate precipitation. Neuberg \& Kobel (1927) and Mehlitz (1930) precipitated pectase from the sap of tobacco and lucerne respectively by the addition of 2 vol. of ethanol. Ethanol precipitation of the enzyme from phosphate extracts resulted in complete loss of activity, although active preparations could be obtained from the sap in this way.

The buffering power of $\mathrm{NaOH}$ extracts is low so that when ammonium sulphate was added to precipitate the protein the pectase was inactivated, due probably to the fall in $\mathrm{pH}$. It was necessary to carry out ammonium sulphate precipitations at $\mathbf{p H}$ values above 7 in a well-buffered solution, and in this respect phosphate extracts were satisfactory. Precipitation then caused no loss of activity. Fractional precipitation showed that all the activity was not precipitated until about $65 \%$ saturation was reached. When fractionation was attempted on a dilute extract (not more than $5 \mathrm{mg} . / \mathrm{ml}$. dry matter) less than $10 \%$ of the activity was precipitated below $45 \%$ saturation with ammonium sulphate. However, with more concentrated solutions the enzyme was adsorbed on material coming out at a lower saturation and as much as $30 \%$ of the activity was precipitated below $35 \%$ saturation with ammonium sulphate. Activity tests could not be carried out in the presence of large amounts of ammonium sulphate as it had an inhibitory effect on the reaction, but the amount present in centrifuged precipitates from ammonium sulphate solutions was not sufficient to interfere seriously with the determinations.

\section{Method of preparation and partial purification}

Well-washed minced fibre was extracted three times with $0.2 \mathrm{M}$-phosphate solution at $\mathrm{pH}$. The volumes of phosphate solution used were approximately 3, 2 and $1 \mathrm{ml} . / \mathrm{g}$. fibre for the successive extracts. The fibre was soaked for about $15 \mathrm{~min}$. for each extract, as it was found that less contaminating material was extracted with short soaking. The $\mathrm{pH}$ drift due to demethylation of pectin was not prevented altogether with the volume of phosphate solution used and the combined extracts had a pH of about 7 . These were centrifuged at 3000 r.p.m. (1400 $\times$ gravity) for $15 \mathrm{~min}$. and the deposit of starch and chloroplast material discarded. At this stage the activity varied between 0.003 and 0.006 unit/mg. dry weight. The supernatant was usually a clear red-brown, but sometimes there was a considerable amount of green chromoprotein material that could not be spun out particularly when nightshade leaves were used. When this occurred, ammonium sulphate was added to $30 \%$ saturation and the precipitate obtained on centrifuging discarded. Ammonium sulphate was then added to $65 \%$ saturation and the solution with precipitated protein was filtered with slight suction through diatomaceous earth (Hyflo supercel, JohnsManville Co. Ltd., Artillery Row, London, S.W. 1) on a Buchner funnel. Filtration was more satisfactory at this stage than centrifugation as the precipitate tended to float. The precipitate was taken up in $0.2 \mathrm{M}$-phosphate solution at $\mathrm{pH} 6$ in a volume about one-tenth that of the original extract. The activity was from 0.019 to $0.028 \mathrm{unit} / \mathrm{mg}$. dry weight and the solution dark brown due to adsorption of coloured substances on the protein precipitate.

When the pH was now lowered to about $4 \cdot 6$ by adding dilute $\mathrm{HCl}$ there was precipitation of some of the protein and the activity of the supernatant fluid was increased to over 0.062 unit $/ \mathrm{mg}$. The $\mathrm{pH}$ 
of the solution was then raised to above 7 by the addition of $\mathrm{Na}_{2} \mathrm{HPO}_{4}$ solution and saturated ammonium sulphate solution was added to $65 \%$ saturation. The precipitate was filtered off, and taken up in phosphate solution at $\mathrm{pH}$ 6. The precipitation at $\mathrm{pH} 4 \cdot 6$ and subsequent salting-out was repeated twice. In the final ammonium sulphate precipitation the fraction below $45 \%$ saturation was discarded; that between 45 and $65 \%$ saturation was taken up in phosphate solution at $\mathrm{pH} 7$ and kept in the refrigerator. The activity had increased to $0 \cdot 109-$ 0.125 unit/mg. dry weight (or $0.78-0.90$ unit/mg. protein-N) and the yield was about $60 \%$ of the units originally extracted. Much of the colour had been removed by repeated precipitation but the final solution was still light brown in colour. Phosphate extracts from tobacco and nightshade differed, in that the former had a larger amount of acid-precipitable material and the latter more protein precipitable at a lower concentration of ammonium sulphate.

Adsorption and elution. Lineweaver \& Ballou (1945) and MacDonnell et al. (1945) have reported that the pectase from alfalfa leaves and citrus peel was adsorbed from salt-free solutions on 'Celite' analytical filter-aid (Johns-Manville Co. Ltd.) and could be eluted with dilute salt solution. Phosphate extracts from fibre and purified concentrates of pectase were dialyzed for $18 \mathrm{hr}$. in cellophan sacs with frequent changes of water. When the $\mathrm{pH}$ value did not fall lower than 6 during dialysis there was only a small amount of precipitate in the sac and the loss of activity was less than $10 \%$; but when the $\mathrm{pH}$ fell to about 5 there was then a larger amount of precipitate on which the enzyme was adsorbed and resulting in a large apparent loss of activity. Adsorption on and elution from 'Celite' analytical filter-aid was tested using both tobacco leaf and orange-peel pectase preparations. Unless adsorption was carried out at a slightly acid $\mathrm{pH}$ value only a small amount of enzyme was adsorbed. At pH 4.8 a purified dialyzed preparation of tobacco pectase gave a bulky precipitate containing most of the activity, although before dialysis the precipitate at this $\mathrm{pH}$ was insignificant. Adsorption at $\mathrm{pH} 5 \cdot 3$, which is higher than that at which precipitation takes place was, however, found to be possible. It was stated by Lineweaver \& Ballou (1945) that pectase could be eluted with $0 \cdot 2 \mathrm{M}-\mathrm{NaCl}$. This was tested, using a preparation of orange-peel pectase and the results of an adsorption-elution cycle are given in Table 3. Elution with $\mathrm{NaCl}$ was not as effective as found by Lineweaver \& Ballou; $\mathrm{Na}_{2} \mathrm{HPO}_{4}$, on the other hand, was considerably better, but one elution removed only $50 \%$ of the adsorbed enzyme. The adsorption and elution of an enzyme preparation from woody nightshade leaves which had not been previously acid precipitated
Table 3. Adsorption and elution of pectase

$(150 \mathrm{ml}$. dialyzed solution of orange-peel pectase at pH $4 \cdot 8+500 \mathrm{mg}$. Celite. Washed with distilled water before elution.)

\section{Solution}

Dialyzed enzyme solution

Filtrate from Celite

Eluate 1: $10 \mathrm{ml} .0 \cdot 9 \% \mathrm{NaCl}$

Eluate 2: $10 \mathrm{ml} .0 .9 \% \mathrm{NaCl}$

Eluate 3: $10 \mathrm{ml}$. 0.2 $\mathrm{M}-\mathrm{Na}_{2} \mathrm{HPO}_{4}$

Eluate 4: $10 \mathrm{ml}$. 0.2 $\mathrm{M}-\mathrm{Na}_{2} \mathrm{HPO}_{4}$

Eluate 5: $10 \mathrm{ml}$. 0.2 $\mathrm{M}-\mathrm{Na}_{2} \mathrm{HPO}_{4}$

$\begin{array}{lc}\begin{array}{c}\text { Activity } \\ \text { units }\end{array} & \begin{array}{c}\% \text { activity } \\ \text { on Celite }\end{array} \\ 0.49 & - \\ 0 \cdot 067 & 86 \\ 0 \cdot 033 & 92 \\ 0 \cdot 026 & 86 \\ 0.22 & 34 \\ 0.07 & 18 \\ 0.035 & 9\end{array}$

resulted in an increase of activity from 0.026 to 0.113 unit/mg. dry weight. A preparation which had been purified by acid precipitation had the activity increased from 0.055 to 0.122 unit/mg. by one adsorption and elution. Most of the colour was removed from enzyme solutions by adsorption and elution as it was not adsorbed on the Celite.

\section{Properties of the enzyme}

Fig. 1 shows the variation of activity with $\mathrm{pH}$. Activity tests were carried out by adding buffer solutions of approximately the $\mathrm{pH}$ required to the

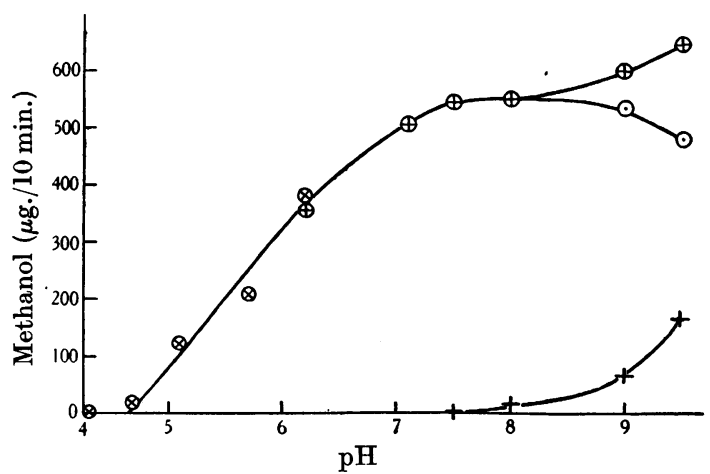

Fig. 1. Variation of pectase activity with $\mathrm{pH} . \otimes-$ citrate buffers; $\oplus-\oplus$ phosphate buffers; +-+ non-enzymic demethylation; $\odot-\odot$ values after subtraction of non-enzymic values.

pectin solution and measuring the final $\mathrm{pH}$ values. For pH values $4 \cdot 3$ to $6 \cdot 2$ citrate buffers were used and phosphate buffers for $6 \cdot 2$ and above. The final concentration of $\mathrm{Na}^{+}$in the solution was $0.09 \mathrm{M}$ for the phosphate buffers and varied between 0.08 and $0.13 \mathrm{M}$ for the citrate. $1 \mathrm{ml}$. dialyzed enzyme solution was added to each and the test carried out in the usual way. Values for non-enzymic demethylation were obtained by carrying out activity tests without addition of enzyme. The whole of the solution was distilled for methanol determination instead of a $5 \mathrm{ml}$. sample. Below pH 4.5 no demethylation occurred and the optimum for pectase activity was near $\mathrm{pH} 8$. 
The course of the demethylating reaction was followed by adding $1 \mathrm{ml}$. enzyme solution to each of a series of flasks containing buffer-substrate and stopping the reaction with $\mathrm{HCl}$ at definite intervals up to $18 \mathrm{~min}$. For at least the first $10 \mathrm{~min}$. the production of methanol followed a straight line relationship. In this time about $40 \%$ of the methanol had been split off, reducing the methoxyl content of the pectin to $3 \cdot 2 \%$.

The variation of activity with substrate concentration is shown in Fig. 2. The tests were made in the usual way except that the more concentrated

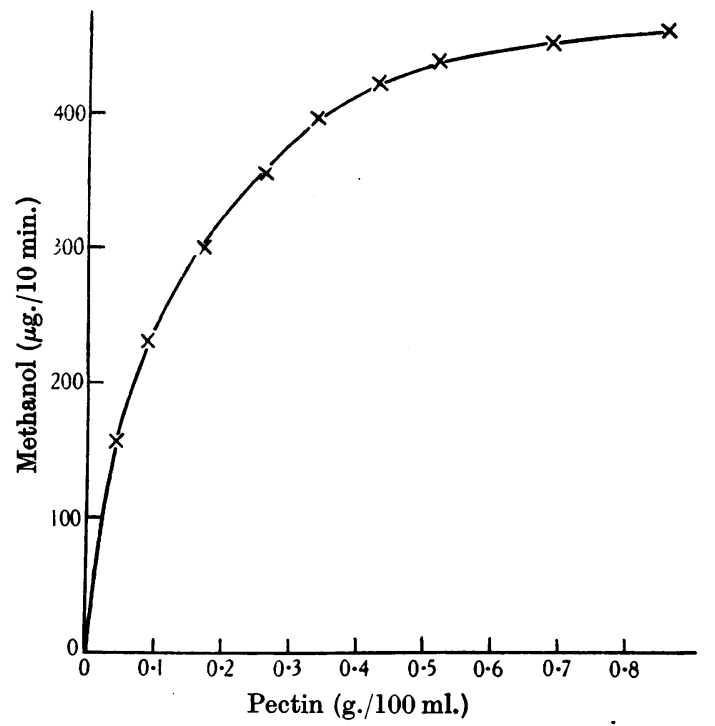

Fig. 2. Variation of pectase activity with substrate concentration.

pectin solutions were neutralized with $\mathrm{NaOH}$ before addition of the $0 \cdot 2 \mathrm{M}$-phosphate solution. The percentage concentration of pectin which gives half the maximum velocity of hydrolysis was found to be $0 \cdot 09$.

A linear relationship (Fig. 3) was found between the amount of methanol liberated and amount of enzyme solution. Fig. 4 gives the results of an experiment on the variation of activity with temperature. Substrate and buffer in separate flasks were brought to the temperature at which the test was to be carried out, mixed, and enzyme solution added. Controls without enzyme were set up at the higher temperatures to correct for non-enzymic demethylation. The optimum temperature for pectase activity is at $55^{\circ}$. Non-enzymic demethylation was not appreciable until $50^{\circ}$. The temperature coefficient $Q_{10}$ between 20 and $30^{\circ}$ is $1.41 ; 30$ to $40^{\circ}$, 1.50 ; and 40 to $50^{\circ}, 1.41$.

Stability. The effect of $\mathrm{pH}$ on the stability of pectase is shown in Fig. 5. A dialyzed enzyme pre-

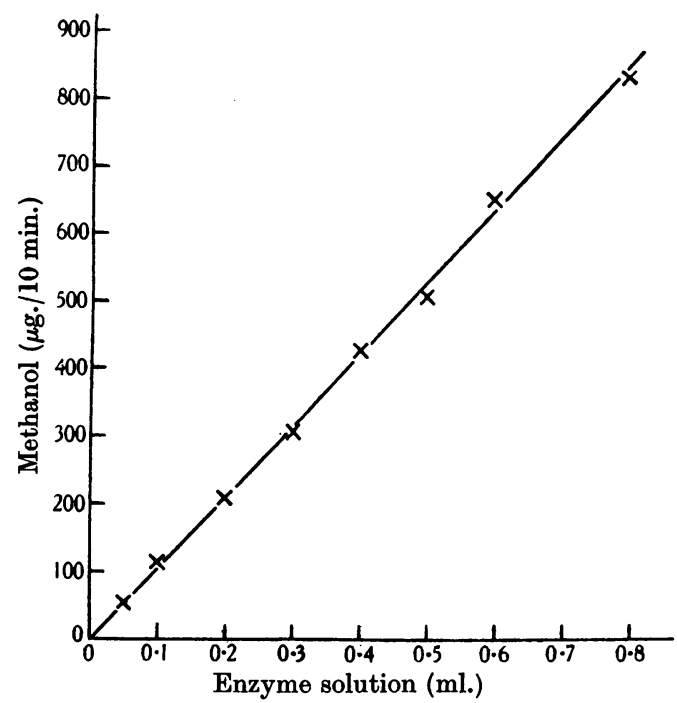

Fig. 3. Variation of activity with pectase concentration.

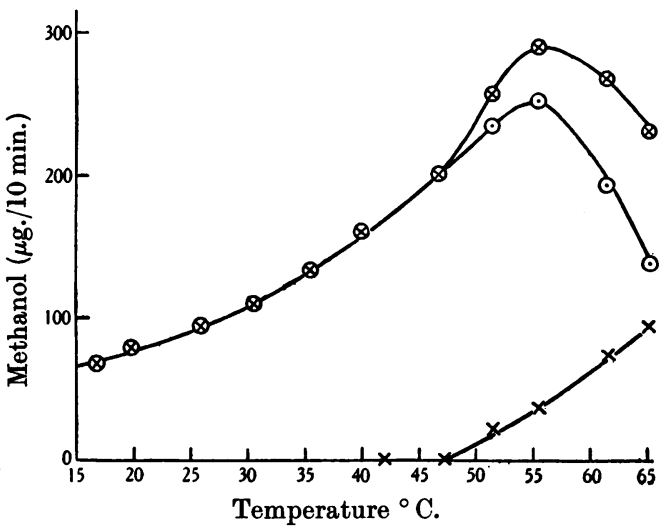

Fig. 4. Variation of activity with temperature. $\otimes-\otimes$ total methanol; $\times-\times$ non-enzymic demethylation; $\odot-\odot$ values after subtraction of non-enzymic values.

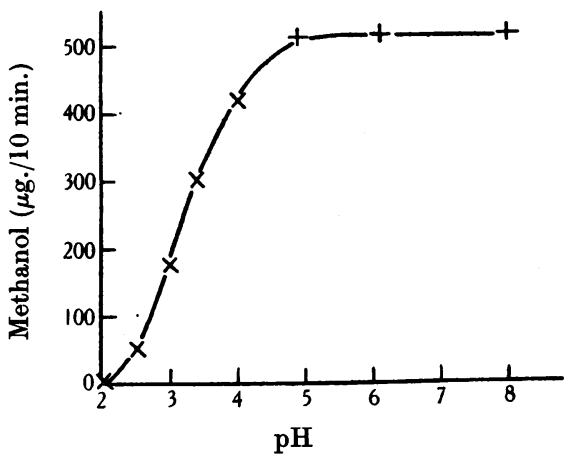

Fig. 5. Effect of $\mathrm{pH}$ on stability of pectase. $\times-\times$ citrate buffers; +-+ phosphate buffers. Activity at pH 8 determined after $5 \mathrm{hr}$. at the given $\mathrm{pH}$. 
paration was diluted tenfold with citrate and phosphate buffers at various $\mathrm{pH}$ values and the activity at $\mathrm{pH} 8$ determined after $5 \mathrm{hr}$. Between $\mathrm{pH} 5$ and 3 some activity, and at $\mathrm{pH} 2$ all activity was lost. There was precipitation of protein between $\mathrm{pH} 3$ and 5, though not at $\mathrm{pH} \mathrm{2,} \mathrm{and} \mathrm{solutions} \mathrm{were}$ centrifuged before determining the activity. Some activity was found to be associated with the precipitate so the loss is not as great as would at first appear. When plotting the curve this activity has been added to that of the solution.

The effect of temperature on the stability was determined by keeping enzyme preparations in phosphate buffer of $\mathrm{pH} 8$ at 70,80 and $91^{\circ}$ for 5 min., cooling and determining the activity at $20^{\circ}$. At $70^{\circ}, 30 \%$ of the activity was lost and at $80^{\circ}$ there was complete inactivation.

Enzyme preparations kept at $4^{\circ}$ in phosphate solutions with $\mathrm{pH}$ values from 6 to 8 gradually lost activity. With some concentrates the loss was much more rapid than with others, but one concentrate after a small initial loss in activity remained stable for 3 months. Loss of activity was much more rapid at room temperature $\left(20^{\circ}\right), 50 \%$ or more being lost in 1 week. Dialyzed solutions lost activity at room temperature more rapidly than when salt was present. It was not possible to increase the specific activity of preparations that had lost activity on keeping by refractionation with ammonium sulphate.

High-speed centrifugation. When purified enzyme preparations with activities of more than $0 \cdot 1$ unit/ mg. were spun at 40,000 r.p.m. (90,000 gravity) there was no pellet and the bottom layer of solution had an activity per ml. only about $20 \%$ higher than the rest of the solution. Partially purified preparations with activities $0.025-0.04 \mathrm{unit} / \mathrm{mg}$. when spun at this speed gave a pellet consisting partly of insoluble material and some soluble which had pectase activity. Above the pellet was a layer with an activity per ml. twice as high as the rest of the solution above, but the specific activities did not differ greatly. In the less purified preparations the enzyme was undoubtedly being partially sedimented due to adsorption on material of higher molecular weight.

\section{Pectase distribution in various species}

Table 4 gives values for the pectase activity of the leaves of a number of plants, and also of citrus peel for comparison. There is considerable variation in the total pectase content and in the relative amounts present in the sap and fibre. Members of the Solanaceae have high pectase contents. The activity of tobacco fibre from different batches of leaves varied between 0.047 and 0.09 unit/g. fibre. The pectase content on a dry weight basis of young tobacco leaves and old leaves which had turned yellow was not significantly different from that of the large green leaves usually used, when the plants were grown under the same conditions.

The plants listed in the table were of unknown manurial history and it was not known how the pectase content was influenced by manurial treatment. Advantage was taken to use an experiment in which tobacco plants infected with potato virus $Y$ were grown with different amounts and combinations of $\mathrm{N}, \mathrm{P}$ and $\mathrm{K}$. Infection with potato virus $Y$ does not cause gross lesions and the plants in the well-manured groups were large and healthy looking. The leaves of each group treated separately were minced and washed as usual. Pectase determinations were made on samples of the sap plus washliquors and on the phosphate extracts of the fibres. Dry weight and $\mathrm{N}$ determinations were made on both fractions. The total amount of pectase in the leaves of the group which had N, P and $K$ was fifteen times the amount in the control group. The activity per g. dry weight associated with the fibre was highest in the groups given nitrogen and varied with the $\mathrm{N}$ content of the fibre. In the groups given $\mathbf{N}$ and $\mathbf{P}$ the proportion of enzyme in the sap was about $30 \%$ compared with about $5 \%$ in all the

Table 4. Pectase distribution in various plant species

\begin{tabular}{|c|c|c|c|c|}
\hline \multirow[b]{2}{*}{ Plant } & \multirow{2}{*}{$\underset{(\mathrm{pH})}{\operatorname{Sap}}$} & \multirow{2}{*}{$\begin{array}{c}\text { Total } \\
\text { activity } \\
\text { in sap } \\
(\%)\end{array}$} & \multicolumn{2}{|c|}{ Activity units/g. } \\
\hline & & & Fibre & Leaf \\
\hline Nightshade (Solanum dulcamara) & $5 \cdot 6$ & 9 & $0 \cdot 060$ & $0 \cdot 024$ \\
\hline Tomato (Lycopersicum esculentum) & $6 \cdot 0$ & 33 & 0.063 & 0.023 \\
\hline Potato (Solanum tuberosum) & $6 \cdot 2$ & 16 & $0 \cdot 069$ & $0 \cdot 015$ \\
\hline Elder (Sambucus nigra) & $6 \cdot 3$ & 8 & $0 \cdot 050$ & $0 \cdot 016$ \\
\hline *Peppermint (Mentha piperata) & $6 \cdot 3$ & 17 & 0.005 & 0.0016 \\
\hline Melilot (Melilotus altissima) & $8 \cdot 6$ & 43 & 0.016 & $0 \cdot 014$ \\
\hline *Clematis (Clematis jackmanni) & $4 \cdot 8$ & 9 & $0 \cdot 009$ & 0.006 \\
\hline White bryony (Bryonia dioica) & $6 \cdot 3$ & 16 & 0.022 & 0.011 \\
\hline Beaked parsley (Chaerophyllum sylvestre) & $5 \cdot 6$ & 9 & 0.026 & 0.010 \\
\hline *Rhubarb (Rheum raponticum) & $4 \cdot 3$ & 15 & 0.007 & 0.0034 \\
\hline Lemon peel (flavedo + albedo) & \multicolumn{4}{|c|}{$0.062 \mathrm{unit} / \mathrm{g}$. peel } \\
\hline Orange peel (flavedo + albedo) & & 0.0 & g. peel & \\
\hline
\end{tabular}

* Represents a single determination only. For the remainder the value is typical of a number of determinations. 
other groups. The influence of manurial treatment on pectase content will be reported in more detail later.

\section{DISCUSSION}

Lineweaver et al. made their activity determinations at $30^{\circ}$ so that all the values given here have to be increased by $40 \%$ to make them comparable with theirs. Their preparations with a specific activity of 2.5 units/mg. protein $\mathrm{N}$ have an activity about twice that of the most active preparations obtained in the present investigation. Adsorption on and elution from Celite did not result in such a large increase in specific activity as found by these workers, which may be due to the presence of a different type of impurity.

The $\mathrm{pH}$ optimum for tobacco pectase given by Kertesz (1936) was at about 6.5, but no attempt was made to keep the $\mathrm{pH}$ constant so the value is probably in error. The values he obtained for nonenzymic demethylation were higher than those obtained here. Lineweaver et al. have shown that the relationship between activity, $\mathrm{pH}$ and salt concentration is so complex that for any optimal $\mathrm{pH}$ value the experimental conditions must be defined. It would appear that tobacco pectase is less heatsensitive than orange-peel pectase, as a temperature of $80^{\circ}$ is needed to destroy all its activity, whereas orange-peel pectase is destroyed at $45-50^{\circ}$.

The pectase content of tobacco leaves was influenced by the manurial treatment of the plants with nitrogen and phosphorus but not appreciably by potassium. In all the groups except those given both $\mathbf{N}$ and $\mathbf{P}$ (these having the highest pectase contents), the percentage of the enzyme which was sap-soluble was low; nitrogen alone did not increase the proportion of sap-soluble enzyme but greatly increased the amount associated with the fibre. The values given for the pectase content of the various species might have differed had the plants been grown under different conditions. However, it is clear that members of the Solanaceae have high pectase contents, and that tobacco leaf fibre is as good a source of the enzyme as citrus peel. The high percentage of sap-soluble pectase and the abnormally high $\mathrm{pH}$ of the sap of melilot are noteworthy.

\section{SUMMARY}

1. Pectase activity was determined by estimating the amount of methanol liberated from pectin under standard conditions.

2. The sap of tobacco leaves contains only a small proportion of the total pectase present, most being associated with the fibre.

3. Extraction of the enzyme is influenced by salt concentration and $\mathrm{pH}$. The enzyme in the extract could be concentrated by precipitation with ammonium sulphate at $65 \%$ saturation from a buffer solution of $\mathrm{pH}>7$, but not with ethanol. An increase in specific activity of enzyme preparations was obtained by removal of the protein precipitated at $\mathrm{pH} 4 \cdot 6$ in the presence of salt. The adsorption of pectase on Celite from salt-free solution was confirmed, and elution with $0 \cdot 2 \mathrm{M}-\mathrm{Na}_{2} \mathrm{HPO}_{4}$ was more effective than with $\mathrm{NaCl}$.

4. The optimum conditions for enzyme activity were found to be $\mathrm{pH} 8$ and $55^{\circ}$. Acidification to $\mathrm{pH} 3$ and heating to $80^{\circ}$ destroyed the enzyme.

5. The pectase content of tobacco leaves was influenced by manurial treatment. The distribution in the leaves of ten other species is given.

I wish to thank the Agricultural Research Council for a grant.

\title{
REFERENCES
}

Bawden, F. C. \& Pirie, N. W. (1944). Brit. J. exp. Path. 25, 68.

Holden, M. (1945). Biochem. J. 39, 172.

Kertesz, Z. I. (1936). Ergebn. Enzymforsch. 5, 233.

Lineweaver, H. \& Ballou, G. A. (1945). Arch. Biochem. 6, 373.
MacDonnell, L. R., Jansen, E. F. \& Lineweaver, H. (1945). Arch. Biochem. 6, 389.

Markham, R. (1942). Biochem. J. 36, 790.

Mehlitz, A. (1930). Biochem. Z. 221, 217.

Neuberg, C. \& Kobel, M. (1927). Biochem. Z. 190 , 232.

\section{The Skin Protease Inhibitory Factor of Plasma}

\author{
By ANNE BELOFF, Department of Biochemistry, Oxford
}

(Received 25 October 1945)

This work arose from the observations made (Beloff $\&$ Peters, $1944 ; 1945 a, b$ ) on the influence of moderate-temperature burns upon a protease of skin. This paper describes the method used for estimating the inhibitory activity of plasma on the skin proteo- lytic system, and the properties and nature of this inhibitory factor. The application of these observations to the previous work on thermal burns will be described separately (Beloff \& Peters, $1945 b)$. 